\title{
ANALISIS KUALITAS PENGELASAN PRESSURE VESSEL PADA LOMBA KOMPETENSI SMK TINGKAT NASIONAL DENGAN STANDAR AWS
}

\author{
Nur Khamdan $^{1}$, Riswan Dwi Djatmiko ${ }^{2}$, Shaffa Azka Ramadhani ${ }^{3}$ \\ ${ }^{1}$ Jurusan Pendidikan Teknik Mesin FT UNY; ${ }^{2}$ Jurusan Pendidikan Teknik Mesin FT UNY; ${ }^{3}$ Teknik Manufaktur FT UNY \\ Email: nur.khamdan2016@student.uny.ac.id
}

\begin{abstract}
This research aimed to study the acceptance level and visual test of weldments in pressure vessel in the national skills competition of vocational students in 2019. The approach of this research is quantitativedescriptive. Data were collected using checklists of quality assessment of the weld results. The tests for quality were pressure test and visual test. This research was conducted at the national skill competition in 2019 at Jogja Expo Center. The sample of this study were 32 werlders. The results revealed that the acceptance level was considerably low, in which only 1 out of 32 participants passed the pressure test. Results from the visual quality were also low due to lack of understanding and knowledge in determining the requirements of pressure vessel welding, especially for the welding code and assembly drawing symbols. Participants were also unable to choose the right welding current, lacks theoretical knowledge of metals characteristics and welding processes types, and low awareness of OSH equipment. Most participant were also lacking in practical knowledge on how to avoid welding defects in the pressure vessel weldments.
\end{abstract}

Keywords: national skill, weldment, pressure vessel, aws standard

\begin{abstract}
ABSTRAK
Penelitian ini bertujuan mengetahui tingkat kelolosan hasil pengelasan pressure vessel pada lomba kompetensi siswa SMK tingkat nasional tahun 2019. Penelitian ini merupakan penelitian deskriptif kuantitatif. Metode pengumpulan data dalam penelitian ini menggunakan check list penilaian kualitas hasil pengelasan siswa dengan uji tingkat kelolosan kebocoran dan uji visual. Penelitian ini dilaksanakan di Jogja expo center (JEC) sebagai tempat LKSN. Sampel dari penelitian ini adalah 32 siswa, analisis data dilakukan dengan analisis deskriptif. Hasil penelitian menunjukkan bahwa: tingkat kelolosan uji pressure vessel masih sangat rendah dimana dari 32 peserta yang lolos uji pressure hanya 1 orang, kualitas hasil visual pengelasan pressure vessel masih rendah hal tersebut disebabkan kurangnya pemahaman dan pengetahuan tentang menentukan persyaratan pengelasan pressure vessel khususnya dalam mengetahui kode pengelasan dan simbol gambar kerja asembly, mengetahui jenis bahan logam, mengetahui jenis proses pengelasan SMAW, GMAW, GTAW dan FCAW serta mengetahui fungsi alat keselamatan dan kesehatan kerja, serta pemahaman terhadap cara untuk menghindari cacat-cacat las pada hasil pengelasan pressure vessel.
\end{abstract}

Kata kunci: LKS nasional, pressure vessel, standar AWS

\section{PENDAHULUAN}

Sekolah Menengah Kejuruan (SMK) merupakan Lembaga pendidikan formal yang menyelenggarakan pendidikan kejuruan pada jenjang pendidikan menengah. Pendidikan kejuruan adalah bagian dari sistem pendidikan yang mempersiapkan seseorang agar lebih mampu bekerja pada satu kelompok pekerjaan atau satu bidang pekerjaan daripada bidang- bidang pekerjaan lainnya. Menurut penjelasan Undang-Undang Nomor 20 Tahun 2003 Pasal 15, pendidikan kejuruan merupakan pendidikan menengah yang mempersiapkan peserta didik terutama untuk bekerja dalam bidang tertentu.

Program pembelajaran keahlian yang dilaksanakan di SMK menyesuaikan dengan kebutuhan dunia kerja. Hal tersebut senada dengan pendapat Pavlova (2009) yang mengungkapkan bahwa pada dasarnya tujuan 
utama pendidikan kejuruan adalah untuk memberikan keterampilan khusus dan pengetahuan tentang dunia industri kepada siswa sebagai bekal untuk memperoleh pekerjaan. Oleh karena itu, lulusan dari SMK diharapkan sudah siap untuk memasuki dunia kerja serta mengembangkan sikap profesional, mampu memilih karir, mampu berkompetisi dan mampu mengembangkan diri, menjadi tenaga kerja tingkat menengah untuk memenuhi kebutuhan dunia usaha dan industry pada saat ini maupun masa yang akan datang. Untuk mencapai tujuan tersebut, maka salah satu usaha yang dilakukan oleh Direktorat Pembinaan SMK (Dit. PSMK), Ditjen Dikdasmen, Kmdikbud menyelenggarakan lomba LKS SMK seluruh Nasional.

Lomba Kompetensi Siswa Nasional Sekolah Menengah Kejuruan (LKSN SMK) merupakan ajang kompetisi untuk mengukur kemampuan kompetensi siswa SMK. Siswa yang akan berkompetisi adalah siswa siswa pilihan dari masing-masing sekolah. Lomba LKSN SMK merupakan lomba yang bertahap dari mulai Lomba LKS Kabupaten, Provinsi, dan Nasional, kompetisi ini adalah kompetisi tahunan yang sudah dimulai sejak tahun $1992 \mathrm{di}$ Jakarta. Kompetisi ini tidak hanya semata-mata untuk mengukur kemampuan siswa SMK, tetapi juga untuk memotivasi peningkatan kompetensi siswa SMK untuk menghadapi dunia kerja (Bakrun, 2018).

$$
\text { LKSN pada tahun } 2019
$$

diselenggarakan pada tanggal 07 s.d. 13 Juli 2019 yang meliputi 32 jenis bidang lomba tingkat nasional salah satu di antaranya adalah lomba pengelasan (welding). LKSN SMK bidang welding pada tahun2019 diselenggarakan dengan beberapa job dan proses pengelasan yang lebih lengkap. Proses pengelasan yang digunakan antara lain: Shielded Metal Arc Welding (SMAW), Gas Metal Arc Welding (GMAW), Gas tungsten arc welding (GTAW) dan Flux Core Arc Welding $(F C A W)$. Sedangkan, job pengelasan yang ditambahkan antara lain job pengelasan Presure vessel dan Structure Alumunium.
Pengelasan merupakan salah satu cara penyambungan logam yang paling efisien sehingga memainkan peranan kunci dalam proses manufaktur dan produksi dalam industri (Heri, 2008). Untuk memperoleh sambungan las yang berkualitas dan memenuhi ketentuan standar, diperlukan personel pengelasan yang berkualifikasi dan memiliki sertifikat kompetensi pengelasan yang diakui oleh lembaga sertifikasi nasional seperti Badan Nasional Sertifikasi Profesi (BNSP). Kualifikasi personel pengelasan secara umum dibagi menjadi welder atau welding operator, welding inspector, welding supervisor, dan welding engineer.

Pengelasan merupakan hal penting yang harus diperhatikan secara detail karena sangat berpengaruh pada kekuatan kontruksi suatu alat dan bukan hanya sekedar kekuatan pada pengelasan tetapi juga visual dari hasil pengelasan juga harus memenuhi standar seperti American Welding Society (AWS) atau Welding Procedure Specification (WPS). Kompetensi lulusan sesuai dengan yang diperlukan lapangan pekerjaan adalah hal yang sangat diharapkan oleh lembaga pendidikan (Putut, 2010).

Profesi pengelasan memegang peranan penting dalam proses pengelasan. Hampir semua industri manufaktur dalam mengerjakan proyeknya memerlukan tenaga kerja welder, tak terkecuali pada proses pembangunan alat dengan menggunakan bahan logam yang selalu mengunakan pengelasan. Pendidikan menengah kejuruan juga mengutamakan pengembangan kemampuan peserta didik untuk melaksanakan jenis pekerjaan tertentu. Dua hal mendasar dalam penyiapan lulusan pendidikan menengah kejuruan adalah tuntutan sikap profesional pada suatu pekerjaan tertentu (Arif, dkk 2015). Untuk menjamin keberhasilan suatu pengelasan dalam proses pengerjaan tugas, siswa harus mendapatkan pengetahuan teori pengelasan yang cukup sebagai modal praktek, dan alat praktik kerja pengelasan yang memadahi, sehingga siswa bisa bekerja dengan sepenuhnya dan penuh semangat. Siswa wajib mendapatkan 
fasilitas dan alat pelindung diri (APD) yang standar di setiap bilik praktik kerja pengelasan, seperti grinda potong dan selep, dan APD seperti sarung tangan, kacamata, apron, dan safety shoes sehingga siswa bisa berkerja dengan tenang dan aman sehingga hasil pekerjaan lebih maksimal.

Keluhan yang di sampaikan oleh para pengajar mata pelajaran Teknik Pengelasan adalah mahalnya biaya kawat elektroda dan spesimen plat baja yang digunakan pada praktik pengelasan. Sebagian dari biaya praktik dikeluarkan hanya untuk melakukan percobaan pengelasan, yang pada akhirnya terbuang percuma sehingga banyak pelaku pengelasan kurang untuk memberikan fasilitas yang standar untuk praktik kerja siswa yang berdampak kepada hasil dan kualitas pekerjaan siswa SMK. Mengikuti standar praktik pengelasan pada umumnya sangat penting dilakukan untuk meningkatkan kompetensi siswa SMK. Hal inilah yang mendasari untuk menganalisis kualitas pengelasan pressure vessel hasil lomba LKSN SMK. Tujuan yang ingin dicapai dari penelitian ini adalah untuk mengetahui tingkat kualitas visual hasil pengelasan pressure vessel pada lomba kompetensi siswa SMK tingkat nasional tahun 2019.

\section{METODE}

Dalam penelitian ini, metode yang digunakan adalah pendekatan deskriptif. Penelitian deskriptif merupakan penelitian yang bertujuan untuk menggambarkan secara sistematik dan akurat mengenai karakteristik mengenai populasi atau mengenai bidang tertentu. Penelitian ini berusaha menggambarkan situasi atau kejadian. Data yang dihasilkan bersifat deskriptif sehingga tidak dimaksudkan untuk mencari penjelasan, menguji hipotesis, membuat prediksi, maupun mempelajari implikasi. Hal ini senada dengan paparan Wagiran (2013:144) penelitian deskriptif merupakan penelitian yang diarahkan untuk memaparkan fakta-fakta, atau kejadiankejadian secara sistematis dan akurat, mengenai sifat dari populasi. Dalam penelitian deskriptif cenderung tidak perlu mencari atau menerangkan hubungan antar variabel dan menguji hipotesis.

Penelitian hasil pengelasan pressure vessel dilakukan di Jogja Expo Center (JEC). Sebagai tempat dilaksanakannya pengambilan data hasil pengelasan siswa SMK dalam Lomba Kompetensi Siswa Tingkat Nasional bidang welding. Penelitian Lomba Kompetensi Siswa Tingkat Nasional bidang welding ini telah dilakukan pada tanggal 09-13 Juni 2019.

Populasi memiliki makna yang cukup beragam, menurut Sugiyono (2008: 289). Populasi adalah wilayah generalisasi yang terdiri atas obyek atau subyek yang mempunyai kualitas dan karakteristik tertentu yang ditetapkan oleh peneliti untuk dipelajari dan kemudian ditarik kesimpulan. Dalam penelitian ini yang menjadi populasi adalah pewakilan siswa siswa SMK dari seluruh provinsi dalam LKS Tingkat Nasional tahun 2019 yang berjumlah 32 siswa.

Teknik pengumpulan data yang digunakan dalam penelitian ini adalah dengan check list. Penilaian kualitas hasil pengelasan pressure vessel siswa LKSN dengan menguji visual diukur dengan alat ukur welding gauge. Instrumen yang digunakan dalam penelitian ini adalah instumen teknik pengelasan standar industri AWS. Instrumen penelitian dapat dilihat pada Tabel 1 dan 2.

Tabel 1. Instrumen pengelasan standar AWS filet.

\begin{tabular}{ll}
\hline \multicolumn{1}{c}{ Nama Kerusakan } & \multicolumn{1}{c}{$\begin{array}{c}\text { Ukuran maksimal yang } \\
\text { diizinkan }\end{array}$} \\
\hline $\begin{array}{l}\text { Cracks/retak } \\
\text { Porositas/worm holes }\end{array}$ & Tidak diizinkan \\
$\begin{array}{l}\text { Lack of side wall fusion/las } \\
\text { cekung tidak terisi logam }\end{array}$ & Total akumulasi 20 mm \\
$\begin{array}{l}\text { Slag inclusion/terak } \\
\text { terperangkap, spatter }\end{array}$ & $\begin{array}{l}\text { Tidak diizinkan lebih dari } 3 \\
\text { mm }\end{array}$ \\
Undercut & 10\% dari panjang \\
$\begin{array}{l}\text { Underfill/incompletely filled } \\
\text { groove/lack of fill }\end{array}$ & $\begin{array}{l}\text { Pengelasan dengan } \\
\text { kedalaman } 1 \text { mm tidak } \\
\text { diizinkan }\end{array}$ \\
Arc strikes/stray arc & Tidak diizinkan
\end{tabular}




\begin{tabular}{ll}
$\begin{array}{l}\text { Kerusakan mekanis } \\
\text { Angular misalignment }\end{array}$ & $\begin{array}{l}\text { Tidak diizinkan } \\
\text { Kemiringan sudut } 3^{0} \\
\text { maksimal perbedaan } \\
\text { ketinggian } 1 \mathrm{~mm}\end{array}$ \\
\hline Nilai total maksimal: 120 & \\
Masuk toleransi nilai: 10 & \\
Tidak masuk toleransi: 0 & \\
\hline
\end{tabular}

Tabel 2.Instrumen Pengelasan Standar AWS Grove

\begin{tabular}{|c|c|}
\hline Nama Kerusakan & $\begin{array}{c}\text { Ukuran maksimal yang } \\
\text { diIzinkan }\end{array}$ \\
\hline Cracks/retak & Tidak diizinkan \\
\hline Porositas/worm holes & maksimal $1 \mathrm{~mm}$ \\
\hline Overlap & Tidak diizinkan \\
\hline $\begin{array}{l}\text { Lack of side wall fusion/las } \\
\text { cekung tidak terisi logam }\end{array}$ & $\begin{array}{l}\text { Total akumulatif max } 20 \\
\text { mm }\end{array}$ \\
\hline $\begin{array}{l}\text { Lack of root fusion/incomplete } \\
\text { root penetrasion }\end{array}$ & $\begin{array}{l}\text { Total akumulatif } \max 20 \\
\text { mm }\end{array}$ \\
\hline $\begin{array}{l}\text { Lack of penetration/tidak terjadi } \\
\text { penetrasi }\end{array}$ & $\begin{array}{l}\text { Panjang } 12 \mathrm{~mm} \text { lebar } 3 \\
\text { mm total max } 15 \mathrm{~mm}\end{array}$ \\
\hline $\begin{array}{l}\text { Slag inclusion/terak } \\
\text { terperangkap, sparter }\end{array}$ & $\begin{array}{l}10 \% \text { dari panjang } \\
\text { pengelasan dengan } \\
\text { kedalaman } 1 \mathrm{~mm}\end{array}$ \\
\hline Undercut & Maksimal $1 \mathrm{~mm}$ \\
\hline $\begin{array}{l}\text { Root concavity/kecekungan } \\
\text { penetrasi }\end{array}$ & Tidak diizinkan \\
\hline Underfill/incompletely filled & $\begin{array}{l}\text { Maksimal } \\
\text { P: <10 mm T: } 1 \mathrm{~mm} \\
\text { P: <10 mm T: } 1,5 \mathrm{~mm}\end{array}$ \\
\hline Linear misalignment & $1 \mathrm{~mm}$ \\
\hline Arc strikes/stray arc & Percikan busur Las \\
\hline Kerusakan mekanis & Tidak diizinkan \\
\hline Angular misalignment & $\begin{array}{l}\text { Kemiringan ujung sudut } \\
30^{\circ}\end{array}$ \\
\hline $\begin{array}{l}\text { Tinggi sambungan } \\
\text { las/cover/facial }\end{array}$ & Maksimal 2 mm \\
\hline Tinggi penetrasi & Maksimal $1.5 \mathrm{~mm}$ \\
\hline
\end{tabular}

Nilai total maksimal: 160

Masuk toleransi nilai: 10

Tidak masuk toleransi: 0

Sesuai dengan tujuan penelitian ini adalah untuk menganalisis kualitas pengelasan siswa SMK dalam LKSN bidang welding khususnya dalam pengelasan pressure vessel tahun 2019. Maka data penelitian yang sudah terkumpul selanjutnya akan dianalisa secara deskriptif. Analisis deskriptif dimaksudkan untuk mengetahui karakteristik masing-masing variabel serta dapat melakukan representasi obyektif masalah penelitian. Dalam suatu penelitian, analisis deskriptif meliputi penyajian distribusi frekuensi setiap variabel, ukuran tendensi sentral (mean, modus, median), dan ukuran dispersi (penyebaran) meliputi standar deviasi dan varian (Wagiran, 2013: 329). Dalam melakukan analisis ini, langkah yang dilakukan yaitu mendeskripsikan data dengan menghitung harga mean (Me), median (Md), modus (Mo).

\section{HASIL DAN PEMBAHASAN}

Hasil yang diperoleh dalam penelitian ini berupa data yaitu meliputi hasil pengelasan presure vessel diikuti oleh 32 peserta yang berasal dari perwakilan SMK seluruh Provinsi di Indonesia. LKSN SMK ini terdiri dari pengetahuan tentang pengelasan dan posisi pengelasan. Job yang dikerjakan adalah membuat sambugan tumpul fillet dan sambungan kampuh $\mathrm{V}$ butt join yang ada pada presure vessel.

Penilaian hasil pengelasan yang digunakan untuk menilai hasil pengelasan pressure vessel siswa SMK adalah dengan standar AWS. Instrumen penilaian hasil pengelasan adalah form untuk menilai hasil pengelasan pressure vessel siswa SMK dengan standar AWS dengan posisi pengelasan fillet dan Grove. Penilaian LKSN SMK bidang welding khususya pengelasan pressure vessel di DIY dilakukan dengan cara melakukan praktik pengelasan pressure vessel bisa dilihat pada Gambar 1.

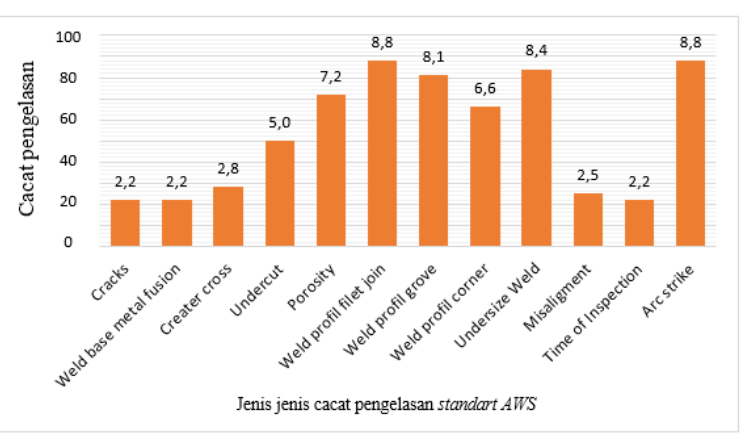

Gambar 1. Diagram hasil pengukuran cacat pengelasan pressure vessel 
Dari hasil penilaian sambungan las pada pengelasan pressure vessel dengan standar AWS dapat diketahui bahwa kualitas sambungan las siswa SMK dengan penilaian standar industri masih mengalami banyak cacat pengelasan. Dari hasil diagram di atas terdapat 12 butir intrumen penilaian uji visual yang menjadi acuan dalam penilaian pengelasan sambungan las pada pressure vessel.

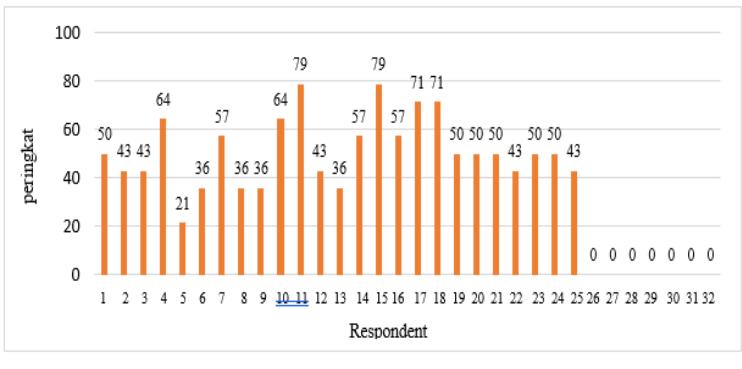

Gambar 2. Diagram hasil peringkat pengelasan pressure vessel

Penilaan dari standar AWS menunjukkan bahwa hasil dari pengelasan pressure vessel siswa SMK pada lomba LKSN SMK tahun 2019. Bidang welding belum ada yang lolos uji visual untuk standar industri yang menggunkan penilaiaan pengelasan dengan standar AWS, dengan nilai maksimal 100. Dari penilaian diagram gambar di atas dapat diketahui seberapa kemampuan siswa dalam melakukan pengelasan presure vessel SMK seluruh Indonesia dalam teknik pengelasan. Instrumen penilaian digunakan untuk mengukur kualitas sambungan las pada pressure vessel yang dibuat oleh peserta LKSN SMK adalah Instrumen yang mengacu pada standar penilaian LKSN. Hasil penilaian tersebut bisa dilihat pada Gambar 2.

Dari penilaian hasil pengelasan pressure vessel LKSN SMK tahun 2019 masih ada butir penilaian yang tingkat kesalahan diatas 50\% seperti butir 4, 5, 6, 7, 8, 9 dan 12 masih terjadi cacat pengelasan seperti, undercut, weld base metal fusion, weld profil grove, weld profil fillet, weld profil corner dan Arc strike. Dari tujuh butir cacat pengelasan yang sering terjadi dapat diketahui bahwa pengalaman, pengetahuan dan kompetensi pengelasan dalam teknik pengelasan itu sangat penting sebagai modal dasar sebagai welder professional yang sesuai standar industri.

Dari hasil kualitas pengelasan pressure vessel antara penilaian juri LKSN dan instrumen AWS menunjukan hasil yang berbeda dari segi kelolosan hasil pengelasan. Penilaian juri LKSN untuk posisi pengelsan pressure vessel dari 32 peserta yang mengikuti LKSN jika dilihat dari persentase kelolosan belum ada yang lolos dari butir pengelasan nilai passing grade yang ditentukan oleh panitia LKSN bidang welding dengan nilai minimum $80 \%$. Untuk penilaian posisi pengelasan pressure vessel dengan standar AWS dari 32 peserta yang mengikuti belum ada yang memenuhi standar industri dari penilaian AWS.

Untuk penilaian pengelasan pressure vessel dengan penilaian LKSN bidang welding dari 32 peserta yang mengikuti terdapat $0 \%$ peserta yang lolos dari passing grade dengan kata lain 0 peserta lolos dengan nilai diatas passing grade 80. Lomba LKSN SMK 2019 bidang pengelasan yang diselengarakan di provinsi DIY dapat diketahui seberapa tingkat kelolosan pengelasan pressure vessel siswa SMK dalam teknik pengelasan dengan penilaian LKSN dan AWS. Dapat dilihat dari tabel di atas diketahui bahwa hasil penilaian dengan uji visual LKSN posisi pengelasan pressure vessel belum ada peserta yang lolos dengan passing grade yang ditentukan panitia sebesar 80. Dalam penilaian uji visual AWS pengelasan pressure vessel belum ada peserta yang lolos untuk memenuhi standar AWS, dikarenakan standar AWS yang mengharuskan nilai maksimal $100 \%$.

Resiko yang terjadi jika cacat pengelasan cracks atau retakan pada pengelasan terjadi adalah kekuatan bahan sambungan las berkurang dikarenakan terjadi retakan pada sambungan pengelasan. Jika diaplikasikan pada pipa minyak atau gas bisa menyebabkan kerusakan dan kerugian yang sangat besar jika terjadi kebocoran. Jika dilakukan uji banding 
terjadi patah pada sambungan pengelasan. Cacat pengelasan underfill adalah cacat pengelasan yang diakibatkan oleh ampere pengelasan yang terlalu rendah sehingga tidak mengisi sisi-sisi sudut kampuh pengelasan dan sisi kampuh yang kotor menjadi faktor dalam terjadinya cacat underfill sehingga sudut ayunan dari elektroda tidak bisa mencairkan bibir kampuh dan sudut elektroda saat pengelasan tidak sesuai sehingga arah cairan logam cairan elektroda tidak menempel dengan sempurna. Resiko yang terjadi jika cacat pengelasan underfill pada pengelasan terjadi adalah mengurangi kekuatan logam pengelasan. Selain itu juga mengakibatkan retakan atau kebocoran jika pengelasan diaplikasikan pada pipa minyak atau gas yang bertekanan. Sambungan pengelasan tidak lolos jika dilakukan uji pressure.

Tabel 3. Skor hasil pengelasan pressure vessel penilaian instrumen LKSN dan Instrumen standar AWS

\begin{tabular}{ccccc}
\hline No & \multicolumn{2}{c}{ LKSN } & \multicolumn{3}{c}{$A W S$} \\
& Pengujian & Visual & Pengujian & Visual \\
\hline 1 & 0 & 53 & 0 & 50 \\
2 & 0 & 48 & 0 & 43 \\
3 & 0 & 55 & 0 & 43 \\
4 & 0 & 68 & 0 & 64 \\
5 & 0 & 35 & 0 & 21 \\
6 & 0 & 35 & 0 & 36 \\
7 & 0 & 60 & 0 & 57 \\
8 & 0 & 35 & 0 & 36 \\
9 & 0 & 35 & 0 & 36 \\
10 & 0 & 68 & 0 & 64 \\
11 & 0 & 73 & 0 & 79 \\
12 & 0 & 45 & 0 & 43 \\
13 & 0 & 40 & 0 & 36 \\
14 & 0 & 55 & 0 & 57 \\
15 & 20 & 68 & 20 & 79 \\
16 & 0 & 45 & 0 & 57 \\
17 & 0 & 78 & 0 & 71 \\
18 & 0 & 68 & 0 & 71 \\
19 & 0 & 45 & 0 & 50 \\
20 & 0 & 40 & 0 & 50 \\
21 & 0 & 45 & 0 & 50 \\
22 & 0 & 30 & 0 & 43 \\
23 & 0 & 53 & 0 & 50 \\
24 & 0 & 48 & 0 & 0 \\
25 & 0 & 45 & 0 & 0 \\
26 & 0 & 0 & 0 & 0 \\
27 & 0 & 0 & 0 & 0 \\
28 & 0 & 0 & 0 & 0 \\
29 & 0 & 0 & 0 & 0 \\
30 & 0 & 0 & 0 & 0 \\
31 & 0 & 0 & 0 & 0 \\
32 & 0 & 0 & 0 & 0 \\
\hline Tot. & 20 & 1270 & 20 & 0 \\
& & & & 0 \\
\hline
\end{tabular}

Dari hasil kualitas pengelasan pressure vessel antara penilaian juri LKSN dan instrumen penilaian AWS menunjukan hasil yang berbeda dari segi kelolosan hasil pengelasan. Penilaian juri LKS untuk posisi pengelsan pressure vessel jika dilihat dari persentase kelolosan belum ada yang lolos dari butir pengelasan nilai passing grade yang ditentukan oleh panitia LKSN dengan nilai minimum $80 \%$.

Untuk penilaian pengelasan pressure vessel dengan standar AWS dari 32 peserta yang mengikuti belum ada yang memenuhi standar industri dari penilaian AWS. Penilaian pengelasan pressure vessel dengan penilaian LKS dari 32 peserta yang mengikuti terdapat $0 \%$ peserta yang lolos dari passing grade dengan kata lain 0 peserta lolos dengan nilai diatas passing grade 80 dan dengan penilaian AWS dari 32 peserta yang mengikuti pengelasan pressure vessel belum ada peserta yang lolos dengan penilaian standar industri yang menggunakan standar AWS, lihat pada Tabel 3.

Hasil penilaian dengan uji visual LKSN posisi pengelasan pressure vessel belum ada peserta yang lolos dengan passing grade yang ditentukan panitia sebesar 80, untuk uji pengelasan pressure vessel penilaian uji pressure LKSN meloloskan 1 peserta dengan nilai 20.

Dalam penilaian uji visual standar AWS dengan standar industri posisi pengelasan pressure vessel belum ada peserta yang lolos untuk memenuhi standar industri dikarenakan standar industri yang sangat kompetitif dan meminta nilai maksimal 100\%. Slag adalah jenis cacat pengelasan yang sering ditemui dalam LKSN SMK Bidang welding. Penyebab terjadinya slag adalah pembersihan terak pada pengelasan sebelumnya kurang bersih sehingga masih ada terak yang tertinggal. Dan bisa juga disebabkan oleh karat pada logam sehingga electron tidak bisa menempel pada logam yang kotor.

Undercut dan porositas merupakan cacat pengelasan yang selalu ada pada hasil pengelasan. Penyebab dari undercut adalah 
ampere pengelasan yang terlalu besar dan gerakan elektroda lambat begitu juga dengan sebaliknya ampere kecil dan gerakan elektroda terlalu cepat. Porositas bisa desebabkan karena pembersihan pada pengelasan sebelumnya yang kurang bersih atau juga pada saat proses persiapan pengelasan pembersihan benda kerja kurang bersih sehingga masih ada minya yang menempel dan kesalahan penggunaan elektroda yang seharusnya di oven sebelum penggunaan akan tetapi melewati proses oven, perhatikan Gambar 3.

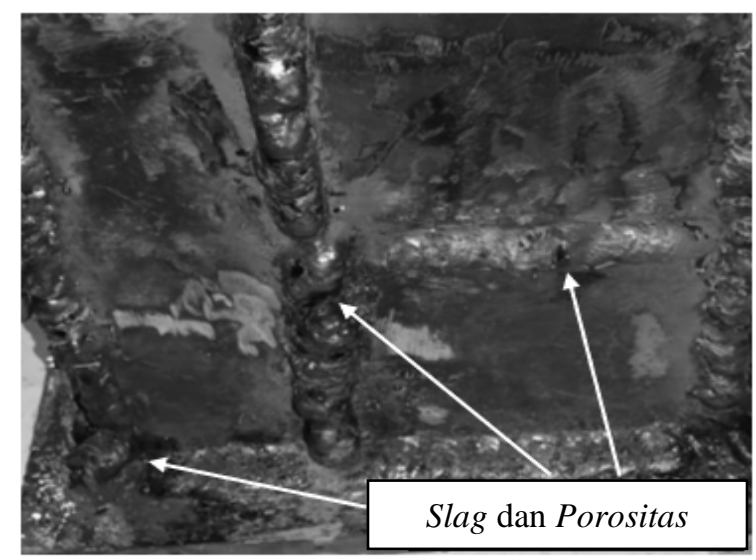

Gambar 3. Cacat pengelasan pressure vessel slag dan, porositas

Kesalahan cacat pengelasan ini terjadi akibat ketidakstabilan dan gerakan elektroda pada saat pengelasan. Start stop pada pengelasan disebabkan karena gerakan elektroda pada saat penyambungan tidak sesuai dengan jalur yang akan disambung. Tinggi pengelasan disebabkan karena gerakan dan sudut elektroda yang salah terlalu lama berada di titik tengah pengelasan dan tidak ada jeda di sisi-sisi pengelasan. Lebar manik las disebabkan karena ketidak stabilan dalam pengelasan tidak melihat jalur sebelumnya sehingga hasil pengelasan menjadi lebar sempit tidak lurus, perhatikan Gambar 4.



Gambar 4. Cacat pengelasan stop star manik las dan reinforcemen. Posisi pengelasan pressure vessel.

\section{SIMPULAN}

Berdasarkan hasil penelitian dan pembahasan yang telah dilakukan mengenai analisis kualitas pengelasan pressure vessel hasil LKSN SMK bidang welding Tahun 2019, maka dapat disimpulkan bahwa kualitas kompetensi siswa SMK di indonesia yang memiliki bidang keahlian teknik pengelasan jika dinilai dengan standar industri menggunakan standar AWS hasilnya masih di bawah kriteria dari penilaian standar industri yang sudah ada. Berdasarkan hasil perhitungan median sebesar 32, sedangkan nilai modus yaitu 0 . Kendala yang terjadi saat perlombaan, seperti kencangya angin di tempat perlombaan sehingga bisa mengakibatkan muncul cacat cacat pengelasan dan menjadi kekurangan dalam memperoleh poin penuh, antara lain cacat pengelasan seperti kebebasan benda kerja dari slag, spatter, arc stray, manik-manik hasil pengelasan tidak teratur sehingga tidak rapi, kebebasan benda kerja dari cacat incomplete penetration dan root of fusion porosity, kebebasan benda kerja dari cacat stopstart pada permukaan cover pass dan root pass, kebebasan benda kerja dari cacat underfill, serta kebebasan benda kerja dari cacat tinggi 
reinforcement yang melebih dari toleransi atau ketentuan dari standart yang ditentukan dari AWS yaitu $2 \mathrm{~mm}$. Dari cacat pengelasan di atas dapat diketahui bahwa kemampuan Teknik pengelasan peserta LKSN SMK masih sangat kurang

\section{DAFTAR RUJUKAN}

Arif Marwanto, Putut Hargiyarto, dan Riswan Dwi Djatmiko. (2015). Analisis Kesalahan Esensial Hasil Pengelasan Peserta Lomba Kompetensi Siswa SMK Tingkat Daerah Istimewa Yogyakarta. Jurnal Pendidikan Teknologi dan Kejuruan, 22, (1), 351-353.

Heri, Sunaryo. (2008). Teknik Pengelasan Jilid 1. Surabaya: Departemen Pendidikan Nasional.

M, Bakrun. (2018). "LKSN SMK upaya meningkatkan kompetensi siswa SMK untuk menghadapi dunia kerja. Diakses tanggal 24 january 2020 dari https://pesertadidik.ditpsmk.net/kategori/ 9/lks.
Pavlova, M. (2009). Technology and vocational education for sustainable development. Queensland: Spinger.

Putut Hargiarto. (2010). Kesesuaian Materi Kegiatan Industri Mitra Dengan Kompetensi Keahlian Pada Program Praktik Industri Mahasiswa Jurdiknik Mesin Fakultas Teknik UNY. Jurnal Pendidikan Teknologi dan Kejuruan, 19, (2), 63-65.

Republik Indonesia. (2003). Undang-Undang Nomor 20 Tahun 2003 tentang Pendidikan Nasional.

Sugiyono. (2008). Metode Penelitian Pendidikan Pendekatan Kuantitatif, Kualitatif dan RnD. Bandung: Alfabeta.

Wagiran. (2013). Metodologi Penelitian Pendidikan (Teori dan Implementasi). Yogyakarta: Deep Publish. 